\title{
Religiosity and spirituality in mental health: nurses' training, knowledge and practices
}

\author{
Religiosidade e espiritualidade em saúde mental: formação, saberes e práticas de enfermeiras
}

Religiosidad y espiritualidad en salud mental: formación, conocimientos y prácticas de las enfermeras

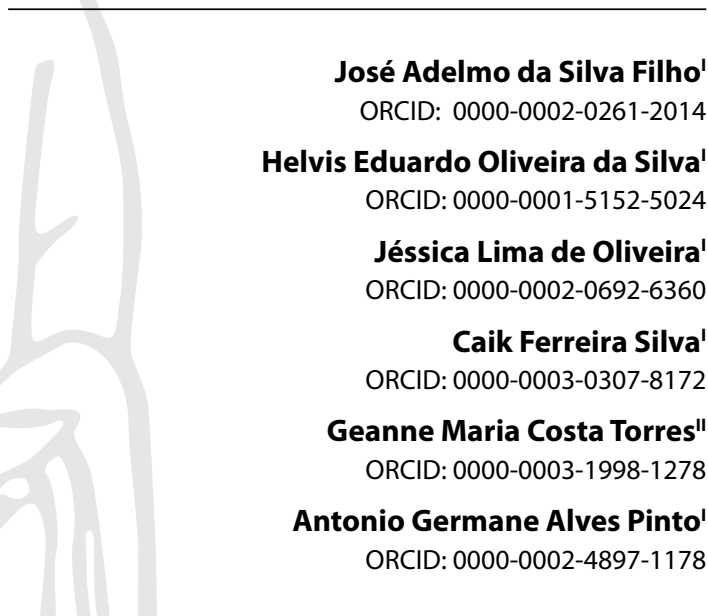

'Universidade Regional do Cariri. Crato, Ceará, Brazil. "Universidade Estadual do Ceará, Fortaleza, Ceará, Brazil.

How to cite this article: Silva Filho JA, Silva HEO, Oliveira JL, Silva CF, Torres GMC, Pinto AGA. Religiosity and spirituality in mental health: nurses' training, knowledge and practices. Rev Bras Enferm. 2022;75(Suppl 3):e20200345. https://doi.org/10.1590/0034-7167-2020-0345

Corresponding author: José Adelmo da Silva Filho E-mail: adelmof12@gmail.com

EDITOR IN CHIEF: Dulce Barbosa ASSOCIATE EDITOR: Margarida Vieira

Submission: $07-13-2020$

Approval: 07-19-2021

\section{ABSTRACT}

Objective: to analyze nurses' training, knowledge and practices in the religiosity/spirituality interface in the context of Psychosocial Care Centers. Methods: a descriptive, exploratory, qualitative study, carried out in a metropolitan region of Ceará. Four nurses were interviewed, and the data were examined using the content analysis technique. Results: four categories emerged from analysis: Deficit in teaching religious and spiritual practices in higher education in nursing; View of the concept of religiosity and spirituality; Religiousness and spirituality as an integral part of the person; Reception of religious and spiritual practices as an aid to treatment. Final considerations: a deficit in nursing undergraduate teaching was identified concerning religiosity and spirituality. However, the interviewed professionals understand the importance of religious and spiritual dimensions in the therapeutic process, even though they do not accurately differentiate the concepts.

Descriptors: Nursing; Mental Health; Religion; Spirituality; Nursing Care.

\section{RESUMO}

Objetivo: analisar a formação, os saberes e as práticas de enfermeiras na interface religiosidade/ espiritualidade no contexto dos Centros de Atenção Psicossocial. Métodos: estudo descritivo, exploratório, com abordagem qualitativa, realizado em uma região metropolitana do Ceará. Foram entrevistadas quatro enfermeiras, sendo os dados examinados pela técnica de análise de conteúdo. Resultados: emergiram quatro categorias da análise: Déficit no ensino das práticas religiosas e espirituais na formação superior em enfermagem; Visão do conceito de religiosidade e espiritualidade; Religiosidade e espiritualidade como parte integrante da pessoa Acolhimento das práticas religiosas e espirituais como auxílio ao tratamento. Considerações finais: identificou-se um déficit no ensino da graduação de enfermagem concernente à religiosidade e espiritualidade. Contudo, as profissionais entrevistadas compreendem a importância das dimensões religiosa e espiritual no processo terapêutico, mesmo não diferenciando os conceitos com exatidão.

Descritores: Enfermagem; Saúde Mental; Religião; Espiritualidade; Cuidados de Enfermagem.

\section{RESUMEN}

Objetivo: analizar la formación, los conocimientos y las prácticas de las enfermeras en la interfaz religiosidad/espiritualidad en el contexto de los Centros de Atención Psicosocial. Métodos: estudio descriptivo, exploratorio con enfoque cualitativo, realizado en una región metropolitana de Ceará. Se entrevistó a cuatro enfermeras y se examinaron los datos mediante la técnica de análisis de contenido. Resultados: del análisis surgieron cuatro categorías: Déficiten la enseñanza de prácticas religiosas y espirituales en la educación superior en enfermería; Visión del concepto de religiosidad y espiritualidad; Religiosidad y espiritualidad como parte integral de la persona; Recepción de prácticas religiosas y espirituales como ayuda al tratamiento. Consideraciones finales: se identificó un déficit en la enseñanza de la licenciatura en enfermería en cuanto a religiosidad y espiritualidad. Sin embargo, los profesionales entrevistados comprenden la importancia de las dimensiones religiosa y espiritual en el proceso terapéutico, aunque no diferencian con precisión los conceptos.

Descriptores: Enfermería; Salud Mental; Religión; Espiritualidad; Atención de Enfermería. 


\section{INTRODUCTION}

Religiosity and spirituality (R/S) are identified as significant aspects of human subjectivity, as they relate to the order of life and construction of people's meaning, as well as influencing the complete physical, mental, cultural and spiritual well-being ${ }^{(1)}$. Issues related to $R / S$ invite us to dialogue between science and faith in healthcare, valuing life and history brought by each person.

The relationship between religiosity, spirituality and health is getting closer. The person's involvement with religion is positively associated with subjective factors such as happiness, affection, high morality and life satisfaction ${ }^{(2)}$. However, this involvement is also capable of generating negative aspects, such as pathological levels of guilt, repression of anger and sexual manifestation s $^{(1)}$.

Spirituality is an intimate existential feeling, in which the person seeks to find meaning in living and being in the world, and it is not necessarily linked to the belief in a greater divinity. On the other hand, religiosity can be understood as a set of beliefs and practices belonging to a doctrine and which, through cults or rituals necessarily involving the perception of faith, are shared and followed by a group of people(3).

Religious and spiritual beliefs and practices are associated with lower incidences of risk behaviors, such as the use of alcohol and other drugs and are elements that help in coping more successfully with stressful situations ${ }^{(4)}$. In therapeutic support, related to disease management, the influence of these beliefs in the lives of people with mental disorders can be highlighted, helping in treatment and coping with their limitations imposed by the health problem ${ }^{(5)}$.

Advances in the mental health field have shaped a care model aimed at community-based psychosocial care and attention. Although mental health policy has been facing setbacks in recent years, the Psychosocial Care Network (RAPS - Rede de Atenção à Saúde) still presents advances in the availability of unique and comprehensive therapeutic initiatives ${ }^{(6)}$.

RAPS comes alive through the interpersonal, intersectoral and dynamic relationships that it operationalizes for mental healthcare. The Psychosocial Care Centers (CAPS - Centros de Atenção Psicossocial) are healthcare services that integrate care and promotion of life with affection, bonds and network communication ${ }^{(7)}$. In this sense, CAPS' disposition for therapeutic innovation with incorporation of $R / S$ in its therapeutic processes is expressed in comprehensive, welcoming and intersubjective initiatives of everyday life.

In this context, the role of nurses in specialized mental health services must ensure comprehensive care for people. These professionals must seek to relate in an interpersonal and affective way, providing conditions capable of helping patients to find their own healthcare measures. Therefore, nurses working in mental health must consider the biopsychosocial and cultural dimensions of people and the interface of these dimensions with nursing care ${ }^{(5)}$.

$\mathrm{R} / \mathrm{S}$ permeate the evolution of nursing over the years, being requirements to practice this science and are impregnated in the thinking, being and doing of the profession ${ }^{(8)}$. However, for these concepts to be satisfactorily integrated, it is necessary that nurses first recognize in themselves this potential of using $R / S$ as strong allies in nursing care ${ }^{(9)}$. The recognition of the religious and spiritual dimensions as a support in the care of problems, sufferings and illnesses experienced at work enhances care practices and therapeutic effectiveness.

The positive/beneficial aspects of the integration of R/S in clinical practice in mental health are cited in research ${ }^{(10-12)}$ that highlight the need to investigate these concepts to establish theoretical, empirical and practical subsidies that support its use as a tool of care in clinical practice, permeating all phases of treatment, whether in preventive and mental health promotion, in facing existing adversities or even in the rehabilitation and social reintegration of people.

Recognizing the relevance of the $R / S$ approach in psychosocial care, as it enables the construction of therapeutic trajectories as a positive reinterpretation, and in care to promote mental health, considering a holistic care to people with mental disorders, the question is: what are nurses' training, knowledge and practices about $\mathrm{R} / \mathrm{S}$ in the context of mental healthcare?

Based on the importance of new perspectives in the process of nurses' training in mental health with the necessary skills to address the religious and spiritual aspects, it is expected to better understand this issue focused on knowledge and practices that give new meaning to mental healthcare, in light of R/S dimensions in the psychosocial universe.

\section{OBJECTIVE}

To analyze nurses' training, knowledge and practices in the religiosity/spirituality interface in the context of Psychosocial Care Centers.

\section{METHODS}

\section{Ethical aspects}

Data collection began after approval by an Institutional Review Board upon a favorable opinion, in compliance with the ethical and legal principles guided by Resolution 466/2012 of the Brazilian National Health Council (Conselho Nacional de Saúde). To preserve confidentiality, the data was used for research purposes only, and participants received alphanumeric expressions in the presentation of results.

\section{Study design}

This is a descriptive, exploratory study with a qualitative approach. The study followed the recommendations of the Consolidated Criteria for Reporting Qualitative Research (COREQ) ${ }^{(13)}$ throughout its preparation.

\section{Methodological procedures, study setting and data source}

The study was carried out in the metropolitan region of Cariri, in the state of Ceará, Brazil, with the CAPS being the locus. Nurses who worked in CAPS in the region participated in the research, and those who met the following inclusion criteria were part of the sample: being in full exercise of the profession during the period of data collection and working on the equipment for at least six months. Nurses who were performing the function of coordinating the equipment without concurrently performing 
activities of assistance to the public were excluded. During the collection period, the setting had six nurses, one of which refused to participate and the other was eliminated by exclusion criteria. Participants were intentionally selected, as they work in CAPS in the region under study.

\section{Data collection and organization}

To minimize possible errors in the preparation and application of the data collection instrument, a pre-test was carried out with the target audience that did not make up the sample, in order to make the themes and aspects to be discussed during the interview. The collection took place in January 2020 through interviews with a semi-structured script. The instrument used was divided into two parts: the first contained information on the sociodemographic characteristics of participants; the second had questions about nurses' training, knowledge and practices regarding R/S.

The interviews were previously scheduled with participants and carried out at the CAPS where the professionals worked, in a reserved and silent space, conducted by a trained researcher, lasting on average 20 minutes each. The objectives and interests of data collection were explained before the beginning of the interviews. The audio of the interviews was recorded and the content was transcribed in full, then read and analyzed.

\section{Data analysis}

Data were organized and coded by two independent researchers and analyzed using the thematic categorical content analysis technique, covering pre-analysis, material exploration and data processing ${ }^{(14)}$ through critical and reflective assessment. In analysis, four important categories emerged: Deficit in teaching religious and spiritual practices in higher education in nursing; View of the concept of religiosity and spirituality; Religiousness and spirituality as an integral part of the person; Reception of religious and spiritual practices as an aid to treatment. These categories were discussed based on the literature relevant to the theme.

\section{RESULTS}

Four nurses aged between 30 and 41 years, with a graduate degree in mental health, with experience in mental health ranging from one to three years and monthly income between 2 and 3 minimum wages participated in the study. Three participants declared themselves brown.

It should be noted that in nurses' discourses, religion was always related to the theme, although the research did not have religion as its central theme, but the analysis of training, knowledge and practices of nurses working in CAPS in relation to R/S.

\section{Deficit in teaching religious and spiritual practices in higher education in nursing}

Regarding the approach to this theme during graduation, it is evident the report of a nurse who attended, in an incipient and superficial way, subjects that deal with these contents. The others do not remember subjects, mandatory or optional, that reveal R/S nuances in mental healthcare, which reveals the need for training to work in service with more solid bases on religious and spiritual dimensions:

In the psychology applied to nursing course, I remember talking about this, but I don't know how to specify it well. I remember you worked on the subject at the time. (Nur1)

Making an analysis, there is not a chair that I studied that addressed religiosity that I remember, none. (Nur3)

\section{As I remember, I don't think so. (Nur4)}

Nur3 and Nur4 reveal the existing gaps in nursing education on $\mathrm{R} / \mathrm{S}$, and it is essential to include these themes in undergraduate and professional education curricula for better care for people with mental disorders, helping to maintain the balance in all dimensions of life.

Participation in scientific events is similar to undergraduate experiences. One respondent participated in an event of this type as an undergraduate, and two others participated in the professional exercise, highlighting the desire to learn about the theme:

Yes, [I participated] during the undergraduate course, but I don't remember very well. I just remember that at some point he addressed the topic. (Nur1)

Only in some courses that this theme was mentioned, the importance, as well as in our training, that we have to respect each patient with their religion and culture. (Nur2)

I participated in a spirit [...] congress [...], where he tried to explain the side of spirituality [...] also in the case of people with schizophrenia, who also tried to explain the side of spirituality in the issue of spiritism [...]. An experience that contributed a lot, especially this issue of epilepsy in children, which I had never seen, he put the videos showing. (Nur3)

There are, then, gaps between theory and practice, knowledge and action, resulting from the deficiency of teaching $\mathrm{R} / \mathrm{S}$ in the training process and participation in scientific events related to the subject. It is evident that the deficit in training implies less understanding of the knowledge that underlies nursing care practices considering $\mathrm{R} / \mathrm{S}$.

The gap in the curricular components of higher nursing courses highlights the need for investments in graduate courses and in-service training as a form of continuing education to meet the needs of people with a broader view of comprehensive care.

\section{View of the concept of religiosity and spirituality}

All interviewees expressed the definition that spirituality is the search for the meaning of life, being a way of finding, in the supernatural, an explanation for existence:

Spirituality is the search for the meaning of free life. Each one has its individual spirituality, being able to seek it in different ways. (Nur1)

Spirituality is conceived by participants as something that strengthens people in their daily lives. In a common sense, 
religiosity becomes the way to achieve spiritual strengthening in different contexts.

Spirituality I understand as something that will give you strength, will show you the right path. It's something that calms you down, that brings tranquility, that brings everything good. Something that gives you the strength to face problems. I'm so attached to spirituality. (Nur2)

I believe it is the well-being, really [...]. If humanity had a little more belief, we would become better beings. And spirituality is just that, you seek in something, in some belief, a better one of you. (Nur4)

Religiosity is one of the different ways to pursue spirituality. It is the spiritual quest in religion. It's more related to religion, type of religion, and how a person focuses on that. (Nur3)

It is evident from the reports that the interviewees seek in religion itself a way to solidify their understanding of religiosity, emphasizing the rituals to renew their strength in the daily confrontations of their existence:

They are two different things, but similar. Religion, people tend to stick more to one detail. It is also a belief in itself, but the tendency is to be more punctual, more material, a way. Let's suppose like this: let's follow a path, I'll follow this here. I believe so. (Nur1)

I take it because my religion is something I have to practice every day, it can be at home and I also need to go to church on Sundays. (Nur4)

In addition to this, religious rituals, such as going to mass, play a successful role in nurses' work in psycho-emotional and spiritual dimensions.

\section{Religiousness and spirituality as an integral part of the person}

For participants, $\mathrm{R} / \mathrm{S}$ is an intrinsic mechanism of the human being, and it is necessary to have a holistic view of caring for people, as nursing care in psychosocial care goes beyond the pathological issue, covering all aspects. Recognition is of great relevance in care practice, as it is an effective catalyst for the promotion and recovery of mental health. The need for balance between mental and spiritual health and all dimensions of the human being can be clearly seen, as shown in the following statements:

People who work in the area know the importance of seeing the mental and spiritual issues as a whole; not seeing the patient only as an illness. When we see it as a whole, we manage to improve the overall picture, [and] the family issue is also easier. (Nur3)

I believe there is a very direct connection, as one thing influences the other, and thus, if you believe that religiosity [...] is part of it, it helps in the issue of the healing process of the disease, not only of mental illness, but of other diseases too. I believe that this ends up leading to an improvement in the entire process itself. (Nur4)

$\mathrm{R} / \mathrm{S}$ is evidenced as an integral part of people in all speeches, either directly or through nurses' comparisons and reflections on their experience in the equipment, expressing the need to use religious and spiritual practices in healthcare based on a holistic view, deconstructing the concept of a fragmented care focused only on pathology:

Religiosity, it is part, it helps, it is part of the disease cure process issue. (Nur1)

There are those who still say, "I believe", but they do not say a religion, and I think it is very important in the sense that I think it is support for the patient's recovery in terms of faith and spirituality. (Nur2)

Furthermore, it appears the need to work in an integrated way to guide all care processes, being essential for treatment, health recovery and the hope of a cure, as expressed in the speeches:

So, the combination of therapies, medications, how to have a spiritual follow-up, I think it's important. (Nur3)

Today I work a lot with this, because I work in an area focused on home care, so we work a lot on this issue with therapies. (Nur4)

The health work process permeated by inter and multidisciplinary practices expands the range of favorable developments in the psychosocial universe, integrating knowledge and practices through a welcoming, comprehensive and humanized approach, supported by various therapeutic approaches to improve the quality of care for people with mental disorders.

\section{Reception of religious and spiritual practices as an aid to treatment}

In the context of care practice, participants report the use of religious and spiritual aspects with people, in order to help promote mental health and, above all, the recovery process, based on the strength of religion and faith in God to face difficulties, as shown in the following statements:

Everyone who arrives here, if he intends to read a Bible for us, we welcome, listen and often dialogue with him the context. We had a case where a patient came with nuns and we decided to pray as the person wanted. (Nur2)

There are patients who welcome them very well. I've witnessed it and I think it's beautiful [...]. There are patients who arrive with suicidal ideation [and] that a doctor asks, "Do you believe in God? [...], look, the only one who takes life is our Lord, that's not good". Guiding patients, saying, "Look, I'm going to help you with the medication, but you have to have faith, you have to have the willpower to remove these thoughts, this suicidal ideation". (Nur4)

It is important to emphasize that this is a position verbalized by all professionals, as an aid for treatment and the therapeutic process, recognizing the religious dimension as one of the aspects that solidifies in people the desire to recover and face the disease:

I believe that even healing, this issue of religiosity influences $a$ lot. (Nur1)

I talk to each person I welcome, I show both sides. I show my opinion, the person is not obliged to believe or accept what I say, 
but I try to show the person the side that would be more correct for the person to follow, in terms of medication, in terms of therapy, religiosity, seeking groups, support. (Nur2)

The religious experience itself is seen as an aid in individual therapeutic approaches when religion is identified in people's medical records, being used as a therapeutic approach after patients' consent. The work with a focus on the religious dimension supports the recovery of health, recognizing the faith in its different contexts, being embraced by those who incorporate it into mental health:

\begin{abstract}
When it comes to guiding both the patient and the family, it's time for me to try to find this faith. Regardless of whether I am Catholic, I ask what is in our anamnesis script, what is the religion, and I try to find his faith. If he really has any religion and if he clings to something. Within that, I try to guide him, because if you don't have any, you're not holding onto anything, man, let's go to faith, may it take you out of the situation you're in. (Nur1)

I try to pass on my professional experience and the experience of my life, even. [...] so, this issue of religion at the time of illness, at the time of health, you have to be grateful, you have to have faith, you have to always focus. (Nur3)
\end{abstract}

It is also noteworthy that religious and spiritual aspects are frequently used to provide comprehensive care to people, through qualified listening and reception in psychosocial care during care, especially in crisis situations, contributing to the process of attenuation of symptoms, added to the conduct based on the use of pharmacological measures to relieve pain and psychological distress.

\section{DISCUSSION}

"Religiosity" and "spirituality" are very specific terms and have great relevance for mental healthcare, as long as they integrate the biopsychospiritual dimensions of people, as observed in the interviews. The various ways of expressing R/S are intertwined with health, with a view to expanding nursing care, valuing other forms of knowledge and practices in psychosocial care.

The integration of R/S in mental healthcare in nursing has shown great success in therapeutic approaches during care. From this perspective, it is necessary to take care of people in a holistic way, which translates into the need to meet each one as a whole, both in the care of the pathology and in the religious and spiritual needs ${ }^{(15)}$.

The inclusion of R/S in nursing care has been shown to be relevant for quality of care and promotion of emotional comfort for patients, but there is still a great deficiency in professionals' training, as observed in participants' expressions. Thus, it is important to emphasize that the skills of professional nurses to identify, assess and use this care need to be deepened with a greater appropriation of concepts through training that can help in practice ${ }^{(16)}$.

There are many barriers that prevent the use of R/S in care, one of them being the lack of education and training, since obstacles such as the deficit in the curricular components of nursing students still persist, in which the use of this therapy is still poorly reported, consequently reflecting on insecurity during nursing care ${ }^{(17)}$. The existing gaps in the theoretical and scientific bases of nursing education are evident, requiring changes in the legislation and standards of higher education in the area, including courses on
$\mathrm{R} / \mathrm{S}$ in the curriculum, in classrooms and in care practices, seeking to break with the biomedical model of healthcare.

The training of these professionals must envision a multiplicity of views and knowledge regarding religious and spiritual issues ${ }^{(18)}$. However, during an analysis of aspects of the use of R/S in healthcare, it was found that the nurses interviewed do not consider themselves properly prepared and safe to give their opinion and/ or practice practices that address the religious and spiritual view of people, in due to little or no training on the subject.

Nurses'narratives had a position aimed at the tendency to restrict their knowledge and actions with regard to the appropriation of religion and spiritual practice in therapeutic approaches, as they did not deepen the theme during the training period. Although this theme is increasingly present and is increasingly recognized in care, most healthcare professionals have not received training to direct $R / S$ practices during consultations. Thus, a gap develops between care and training on the importance of working $\mathrm{R} / \mathrm{S}$ during nursing care $^{(3)}$.

The results show that spirituality is recognized by nurses who work with mental health as an effective measure in the process of coping with mental illnesses. Thus, spirituality is seen as an existing connection between the supernatural and the human, through beliefs and values, which modify a person's perception of themselves and the world, giving meaning to human life ${ }^{(19)}$.

At the time of the consultation, it is possible that professionals tend to share their own spiritual experiences, regardless of the religion each one claims to follow, in the expectation that spirituality can favor people's therapeutic process. However, nurses have a strong power of influence, and by exposing their knowledge and spiritual experiences, they can bias patients'responses at the time of anamnesis, leading to distortion of results, as the person starts to demonstrate only what is acceptable to professionals ${ }^{(20)}$.

Regarding religiosity, many professionals cannot differentiate it from spirituality, understanding them, in many moments, as similar or equal. These are two different realities, but the complexity of this subject allows individuals to present themselves confused and not able to explain it. Thus, given the confusion determined by the theme, it is deemed necessary to be more cautious when inserting spirituality and faith in mental healthcare, as this is an unstable scenario(21-22).

Spirituality has contributed a lot to the health-disease-care process, and that is why it is considered important that each person has their own spiritual beliefs, so that they can feel supported in times of difficulties and uncertainties caused by the disease. Religion allows people and their families to better understand the suffering caused by diseases, especially those of a psychic nature, enabling a better management of the situation, alleviating the feelings of anguish and impotence that are very present during this process ${ }^{(23)}$.

Spirituality directly contributes to the empowerment of people to deal with psychic suffering, much observed in the mental healthcare scenario, as individuals find a source of support in the supernatural. However, it is observed that religiosity is still not a much discussed topic in mental health services, being shyly introduced by some healthcare professionals who believe in faith as a fundamental part of the healing process ${ }^{(24)}$. It is necessary to strengthen R/S and mental health interrelationship, in order to facilitate the therapeutic process of people with mental disorders, leading them to alleviate their suffering. 
This study demonstrates that participants consider the spiritual side of people to be important, although healthcare professionals claim not to have much mastery of the theme "spirituality" associated with mental health, considering that during training they had little or no contact with it. The need to modify this scenario is perceived, as the spiritual care of people is understood as part of professionals' clinical practice ${ }^{(17,25)}$. The appreciation of this experience by nurses in mental health services' daily routine represents a fundamental component for working with human life, significantly influencing the way of thinking, acting and taking care of themselves.

It is understood that nursing practices must be carried out comprehensively, breaking with the biomedical model of the past and focusing not only on the disease, but on a person's biopsychospiritual experiences. In this way, healthcare professionals provide more humanized, holistic care, centered on the person in its dimensions of uniqueness and plurality, while understanding, respecting and even encouraging the individual beliefs and values of each person ${ }^{(26-27)}$.

Identity is believed to be strongly influenced by the doctrine a person believes. Thus, spirituality is seen as an integral part of the human being, determining their behavior in the environment in which they are inserted. Moreover, spiritual beliefs play an important role in the development of therapeutic relationships with professionals, as they interfere with treatment adherence and patient cooperation. In this sense, complementary religious and spiritual therapies, which include rituals and prayers, are presented as efficient tools both in psychiatric disorders and in physical conditions ${ }^{(28)}$.

Many healthcare professionals claim to be religious, demonstrating that they believe in spirituality as a central component of the healing process. Spiritual care helps nursing practice while enabling the development of a connection with the person, promoting their well-being through the feeling of support that is offered to them. However, barriers to the insertion of spiritual nursing care in clinical practice are still perceived, resulting from professionals' lack of knowledge as well as the lack of preparation to carry out this care ${ }^{(18)}$.

Given the above, it is inferred that R/S can positively affect people's physical and mental health. Therefore, it is necessary to address the issue in the context of training healthcare professionals so that they can meet the spiritual needs of their patients. Therefore, it is considered opportune to train nurses to work on the triad religiosity, spirituality and health in the care of people with mental disorders, being relevant for the proper exercise of their care functions.

\section{Study limitations}

The absence of male participants stands out as a limitation, due to the lack of services during the collection period, as well as the lack of other professional categories working in CAPS. Although the sample is from a region of Ceará, the understanding of the phenomenon can be applied to the reality of different regions of the country.

\section{Contributions to nursing, health and public policies}

The study presents subsidies for the practice of mental health nursing in a holistic way, understanding people in comprehensiveness of care. It also points to a deficit in academic training, which makes rethinking the ways of teaching, acting and approaching nurses in specialized mental health services.

\section{FINAL CONSIDERATIONS}

In this study, it is observed that professional nurses working in mental health services understand the importance of $R / S$ in the therapeutic process, changing the way they face the disease and giving a new meaning to life. Furthermore, most participants claim to follow a religion, and this contributes to their perception of the relationship between $\mathrm{R} / \mathrm{S}$ and mental health.

However, despite being a theme that is widely discussed in people's daily lives, there is a deficit in nurses' training, since during graduation there is almost no approach of students with the theme and, after completing the course, few they have the desire and curiosity to know more about the subject in order to implement it in their professional practices. The inclusion of R/S in the training of healthcare professionals, bringing the mystic to the scientific, recognizing their differences and limitations, makes them more prepared to deal with people with mental disorders.

The findings demonstrate that the use of this theme in mental health services is expressed as a driving force behind the transformation of care, through a multidisciplinary approach and altruistic knowledge. Therefore, the importance that the religious and spiritual dimensions exert in people's lives is recognized, proving to be relevant to discuss the subject in the context of mental health, considering the beneficial aspects that have been observed, with still much to be studied.

\section{ACKNOWLEDGMENTS}

We would like to thank all study participants.

\section{REFERENCES}

1. Melo CF, Sampaio IS, Souza DLA, Pinto NS. Correlação entre religiosidade, espiritualidade e qualidade de vida: uma revisão de literatura. Estud Pesqui Psicol [Internet]. 2015[cited 2019 Dec 11];15(2):447-64. Available from: http://pepsic.bvsalud.org/pdf/epp/v15n2/v15n2a02.pdf

2. Barricelli ILFOBL, Sakumoto IKY, Silva LHM, Araujo CV. Influência da orientação religiosa na qualidade de vida de idosos ativos. Rev Bras Geriatr Gerontol. 2012;15(3):505-15. https://doi.org/10.1590/S1809-98232012000300011

3. Murakami R, Campos CJG. Religião e saúde mental: desafio de integrar a religiosidade ao cuidado com o paciente. Rev Bras Enferm. 2012;65(2):361-7. https://doi.org/10.1590/S0034-71672012000200024 
4. Leite IS, Seminotti EP. A influência da espiritualidade na prática clínica em saúde mental: uma revisão sistemática. Rev Bras Cienc Saude [Internet]. 2013[cited 2020 Feb 6];17(2):189-96. Available from: https://periodicos.ufpb.br/ojs2/index.php/rbcs/article/view/14102

5. Salimena AMO, Ferrugini RRB, Melo MCSC, Amorim TV. Understanding spirituality from the perspective of patients with mental disorders: contributions to nursing care. Rev Gaucha Enferm. 2016;37(3):e51934. https://doi.org/10.1590/1983-1447.2016.03.51934

6. Amarante P, Nunes MO. Psychiatric reform in the SUS and the struggle for a society without asylums. Cienc Saude Colet. 2018;23(6):2067-74. https://doi.org/10.1590/1413-81232018236.07082018

7. Lima DKRR, Guimarães J. Articulação da rede de atenção psicossocial e continuidade do cuidado em território: problematizando possíveis relações. Physis. 2019;29(3):e290310. https://doi.org/10.1590/s0103-73312019290310

8. Pilger C, Macedo JQ, Zanelatto R, Soares LG, Kusumota L. Perception of the nursing staff of an intensive care unit regarding spirituality and religiosity. Cienc Cuid Saude. 2014;13(3):479-86. https://doi.org/10.4025/cienccuidsaude.v13i3.19788

9. Siqueira HCH, Cecagno D, Medeiros AC, Sampaio AD, Rangel RF. Spirituality in the health-illness-care of the oncological user process: nurse's outlook. J Nurs UFPE. 2017; 11 (8):2996-3004. https://doi.org/10.5205/1981-8963-v11i8a110202p2996-3004-2017

10. Koenig HG. Religion, spirituality and psychotic disorders. Arch Clin Psychiatry. 2007;34(suppl 1):95-104. https://doi.org/10.1590/ S0101-60832007000700013

11. Guimarães HP, Avezum Á. O impacto da espiritualidade na saúde física. Arch Clin Psychiatry. 2007;34(suppl 1):88-94. https://doi. org/10.1590/S0101-60832007000700012

12. Moreira-Almeida A. O crescente impacto das publicações em espiritualidade e saúde e o papel da Revista de Psiquiatria Clínica. Arch Clin Psychiatry. 2010;37(2):41-2. https://doi.org/10.1590/S0101-60832010000200001

13. Tong A, Sainsbury P, Craig J. Consolidated criteria for reporting qualitative research (COREQ): a 32-item checklist for interviews and focus groups. Int J Qual Health Care. 2007;19(6):349-57. https://doi.org/10.1093/intqhc/mzm042

14. Minayo MCS. O desafio do conhecimento: pesquisa qualitativa em saúde. 14a ed. São Paulo: Hucitec; 2014.

15. Caldeira S, Carvalho EC, Vieira M. Between spiritual wellbeing and spiritual distress: possible related factors in elderly patients with cancer. Rev Latino-Am Enferm. 2014;22(1):28-34. https://doi.org/10.1590/0104-1169.3073.2382

16. Nascimento LC, Santos TFM, Oliveira FCS, Pan R, Flória-Santos M, Rocha SMM. Spirituality and religiosity in the perspectives of nurses. Texto Contexto Enferm. 2013;22(1):52-60. https://doi.org/10.1590/S0104-07072013000100007

17. Cordero RD, Lucchetti G, Fernández-Vazquez A, Badanta-Romero B. Opinions, knowledge and attitudes concerning "spirituality, religiosity and health" among health graduates in a Spanish university. J Relig Health. 2019;58(5):1592-604. https://doi.org/10.1007/s10943-019-00780-3

18. Hawthorne DM, Gordon SC. The invisibility of spiritual nursing care in clinical practice. J Holist Nurs. 2020;38(1):147-55. https://doi. org/10.1177/0898010119889704

19. MahdiNejad J-E-D, Azemati H, Habibabad AS. Religion and spirituality: mental health arbitrage in the body of mosques architecture. J Relig Health. 2020;59(3):1635-51. https://doi.org/10.1007/s10943-019-00949-w

20. Maraldi EO. Response bias in research on religion, spirituality and mental health: a critical review of the literature and methodological recommendations. J Relig Health. 2020;59(2):772-83. https://doi.org/10.1007/s10943-018-0639-6

21. Thiengo PCS, Gomes AMT, Mercês MC, Couto PLS, França LCM, Silva AB. Spirituality and religiosity in health care: an integrative review. Cogitare Enferm. 2019;24:e58692. https://doi.org/10.5380/ce.v24i0.58692

22. Lavorato-Neto G, Rodrigues L, Turato ER, Campos CJG. The free spirit: spiritualism meanings by a nursing team on psychiatry. Rev Bras Enferm. 2018;71(2):301-9. https://doi.org/10.1590/0034-7167-2016-0428

23. Silva GCN, Reis DC, Miranda TPS, Melo RNR, Coutinho MAP, Paschoal GS, et al. Religious/spiritual coping and spiritual distress in people with cancer. Rev Bras Enferm. 2019;72(6):1534-40. https://doi.org/10.1590/0034-7167-2018-0585

24. Lavorato Neto G, Rodrigues L, Silva DAR, Turato ER, Campos CJG. Spirituality review on mental health and psychiatric nursing. Rev Bras Enferm. 2018;71(suppl 5):2323-33. https://doi.org/10.1590/0034-7167-2016-0429

25. Harmuch C, Cavalcante MDMA, Zanoti-Jeronymo DV. Religião e espiritualidade no ensino e assistência de enfermagem na visão dos estudantes: uma revisão. Rev Uningá [Internet]. 2019[cited 2020 Mar 15];56(S2):243-54. Available from: http://revista.uninga.br/index.php/ uninga/article/view/938

26. Lasair S. A narrative approach to spirituality and spiritual care in health care. J Relig Health. 2020;59(3):1524-40. https://doi.org/10.1007/ s10943-019-00912-9

27. Chiang YC, Lee HC, Chu TL, Han CY, Hsiao YC. The impact of nurses' spiritual health on their attitudes toward spiritual care, professional commitment, and caring. Nurs Outlook. 2016;64(3):215-24. https://doi.org/10.1016/j.outlook.2015.11.012

28. Qureshi NA, Khalil AA, Alsanad SM. Spiritual and religious healing practices: some reflections from Saudi national center for complementary and alternative medicine, Riyadh. J Relig Health. 2020;59(2):845-69. https://doi.org/10.1007/s10943-018-0677-0 